\title{
PENINGKATAN KETERAMPILAN MENGARANG MELALUI MEDIA GAMBAR PADA SISWA SD NEGERI 01 SEMANGET
}

\author{
Jungai Sumarlin \\ SD Negeri 01 Semanget, Kecamatan Entikong Indonesia \\ email: jungai@yahoo.com
}

\section{Received: 13 Maret 2019 Accepted: 1 Juni 2019 Published: 30 Juni 2019}

\begin{abstract}
Abstrak
Penelitian ini bertujuan untuk mengetahui peningkatan keterampilan mengarang Bahasa Indonesia siswa kelas VI SD Negeri 01 Semanget yang berjumlah sebanyak 38 siswa/i. Bentuk penelitian adalah penelitian tindakan kelas yang dilaksanakan sebanyak 2 (dua) siklus. Instrumen yang digunakan untuk mengumpulkan data adalah soal tes dan lembar pengamatan aktivitas. Berdasarkan pelaksanaan dan hasil penelitian disimpulkan bahwasanya media gambar dalam kegiatan pembelajaran sangat membantu siswa dalam memahami materi pelajaranserta dapat meningkatkan keterampilan mengarang siswa.
\end{abstract}

Kata kunci: media gambar, keterampilan mengarang

\section{Abstract}

This study aims to determine the improvement of Indonesian language writing skills of class VI students of SD Negeri 01 Semanget which numbered 38 students / $i$. The form of research is classroom action research carried out in 2 (two) cycles. The instruments used to collect data are test questions and activity observation sheets. Based on the implementation and results of the study, it was concluded that the media image in learning activities greatly helped students in understanding the students 'learning material can improve students' writing skills.

Keywords: media images, composing skills

(C) 2019 LPPM IKIP PGRI Pontianak, Indonesia

\section{PENDAHULUAN}

Salah satu sarana komunikasi, interaksi, dan pemecahan masalah membutuhkan kemampuan dalam berbahasa. Bahasa adalah sistim lambang bunyi yang digunakan oleh anggota suatu masyarakat untuk bekerjasama, berinteraksi, dan mengidentifikasi diri (KBBI 2008). Dalam praktik penggunaannya untuk beriteraksi sehari-hari kita kenal ada bahasa lisan (berbicara) dan bahasa tulis (menulis). Bahasa tulis dapat diperoleh melalui pembelajaran di lembaga pendidikan.

Pada kurikulum 2006, pembelajaran Bahasa Indonesia di Sekolah Dasar meliputi empat aspek keterampilan berbahasa yang harus dikuasai siswa. Yaitu menyimak atau mendengarkan, berbicara, membaca, dan menulis. Salah satu keterampilan berbahasa yang akan dipaparkan 
berikut adalah keterampilan menulis. Seseorang pandai dalam bahasa lisan, belum tentu pandai dalam bahasa tulisan. Karena itu seseorang bisa dalam bahasa tulisan, ia harus menguasai aturanaturan menulis yang benar.

Menurut Kamus Besar Bahasa Indonesia (KBBI 2008), menulis berarti membuat huruf, angka dengan pena (pensil, kapur, dan sejenisnya) dan melahirkan pikiran atau perasaan (seperti mengarang atau membuat surat) dengan tulisan. Jadi menulis dapat diartikan membuat huruf dan angka dengan pena untuk melahirkan pikiran seperti mengarang dengan bentuk tulisan.

Pembelajaran Bahasa Indonesia menulis bersifat produktif artinya kegiatan berbahasa yang dapat menghasilkan karya tulis tak terbatas banyaknya. Dalam menulis, Seorang penulis harus memahami kode-kode dalam pentuk tulisan. Seorang penulis juga harus memahami konversi-konversi dalam ejaan, kata, frasa, kalimat, paragraf, dan teks/wacana sehingga dapat memproduksikan tulisan.

Sebagai keterampilan aktif produktif, pembelajaran menulis bagi siswa harus dibimbing sungguh-sungguh oleh guru. Hal ini sejalan dengan pendapat Santoso \& Suwignyo (2012) bahwa sebagai keterampilan aktif produktif, menulis harus mendapat perhatian yang penuh dalam pembelajaran Bahasa dan Sastra Indonesia, khususnya di sekolah dasar. Dalam pelaksanaannya, siswa harus benar-benar kegiatannya menulis. Guru tidak boleh membiasakan diri dengan memberikan siswa pekerjaan rumah (PR) tentang menulis, seperti menulis surat, menulis pidato, menulis dialog, dan sebagainya. Sebab itu menulis memerlukan bimbingan terutama dalam penggunaan tanda baca, ejaan, kata, frase, dan kalimat yang benar. Dengan demikian keterampilan menulis ini harus benar-benar mendapat perhatian penuh.

Mengarang cerita yang dimaksud dalam penelitian ini adalah mengarang cerita bentuk teks percakapan bukan mengarang cerita bentuk prosa. Isi teks percakapan menceritakan sesuatu atau merupakan cerita.

Pembelajaran Bahasa Indonesia aspek menulis di sekolah dasar untuk meningkatkan kemampuan siswa membuat karangan sangat perlu dan dirasakan masih kurang. Banyak siswasiswi membuat suatu laporan dan ringkasan dalam satu paragraf pun masih tidak sempurna. Hal ini menandakan keterampilan mengarang pada siswa masih perlu ditingkatkan. Seperti yang kita ketahui bahwa kegiatan mengarang adalah merangkaikan kata demi kata menjadi kalimat, rangkaian kalimat menjadi paragraf. Antar kalimat saling ada keterkaitan makna. Hingga 
terbentuk sebuah paragraf. Sebuah paragraf sudah dapat disebut karangan pendek. Dengan demikian keterampilan mengarang perlu ditingkatkan.

Di Sekolah Dasar Negeri 01 Semanget pembelajaran menulis yaitu mengarang masih mengalami kesulitan. Demikian yang terjadi pada siswa kelas VI. Hasil belajar siswa kelas VI dalam hal menulis karangan sangat tidak memuaskan. Hasil pembelajaran sebelum melakukan penelitian dengan tugas dilakukan secara individu, terdapat 58\% (22) siswa dari 38 siswa yang tidak tuntas. Seperti terlihat pada Tabel 1.

Tabel 1.1 Rekap ketuntasan belajar pra penelitian

\begin{tabular}{ccc}
\hline \multicolumn{2}{c}{ Ketuntasan } & Jumlah \\
Tuntas & Tidak tundas & \\
\hline $42 \%$ & $58 \%$ & $100 \%$ \\
$(16$ siswa $)$ & $(22$ siswa $)$ & $(38$ siswa $)$ \\
\hline
\end{tabular}

Dari hasil belajar yang tidak memuaskan itu peneliti bersama kolaborator melakukan analisa pekerjaan siswa. Aspek yang dinilai terhadap pekerjaan siswa meliputi: (1) kesesuaian topik dengan isi; (2) kemampuan mengembangkan ide/karangan,; (3) penggunaan tanda baca; dan (4) penggunaan ejaan serta kerapian karangan juga turut menjadi perhatian. Masalah belajar yang ditemukan adalah: (1) siswa sulit dalam mengembangkan ide yang kemudian dituangkan ke dalam bentuk tulisan; (2) siswa belum mampu menggunakan kode bahasa/tanda baca dengan tepat; dan (3) siswa masih lemah dalam penggunaan ejaan pada tulisan. Kelemahan siswa terdapat pada 3 (tiga) aspek di atas, menyebabkan siswa belum mampu menguasai keterampilan mengarang dengan baik sehingga baru $42 \%$ (16) siswa tunas dan masih ada 58\%(22) siswa belum tuntas KKM Bahasa Indonesia 65.

Ketidaktuntasan disebabkan siswa belum mampu memngembangkan karangan. Siswa belum mampu menggabungkan idenya dengan memilih pilihan kosa kata Bahasa Indonesia yang tepat. Kesulitan siswa kurang menguasai makna kalimat yang disusunya sehingga, kadangkadang kalimat yang dibuat memiliki makna terbalik. Penggunakan tanda baca belum tepat tempatnya, hal ini menandakan siswa kurang paham terhadap penggunaanya. Penggunaan huruf kapital dan kata depan masih salah. Siswa kurang usaha dalam mengerjakan tugas. Wajar waktu pembelajaran 90 menit ( 3 x 35 menit) nyaris tidak cukup untuk menyelesaikan pekerjaan.

Faktor lain yang menjadi pemicu rendahnya hasil belajar adalah siswa kurang memperhatikan penjelasan guru atau tidak mengikuti pembelajaran dengan sungguh-sungguh. 
Terlepas dari kesulitan yang dialami siswa tersebut di atas adalah, kegiatan pembelajaran yang bersifat konfensional. Guru lebih mengandalkan ceramah kemudian pemberian tugas. Pada saat kegiatan pembelajaran sebelumnya, guru tidak menggunakan alat bantu sehingga hanya sedikit siswa yang dapat menerima pelajaran dengan benar. Tidak semua siswa memiliki kemampuan yang sama. Setiap siswa memiliki karakter belajar yang berbeda. Ada yang cepat ada yang lambat. Pada saat pembelajaran, tidak ada sesuatu yang dapat memancing perhatian siswa untuk mengarahkan pandangan dan pikirannya terhadap proses pembelajaran yang dilakukan guru. Siswa kurang memperhatikan pembelajaran. Ada yang memperhatikan tetapi pikiran menerawang kurang nyambung ke materi pembelajaran. Sesuatu yang dimaksudkan adalah pelibatan media sebagai alat bantu belajar.

Pembelajaran melibatkan penggunaan media menuntut guru kreatif dalam menyiapkan media yang sesuai. Guru kreatif adalah mereka yang secara teratur menempatkan diri mereka disekitar ide-ide baru yang muncul dari berbagai sumber (Deni Koswara dan Hatimah, 2008:40). Oleh karenanya kreativitas setiap guru akan sangat mempengaruhi kualitas pembelajaran yang juga berimplikasi pada kreativitas peserta didik. Dasar paparan fakta hasil belajar siswa kelas VI serta kendala-kendala yang dialami di atas, maka peneliti memandang fenomena tersebut merupakan problem belajar serius yang harus dicari solusi untuk perbaikan dan peningkatannya. Oleh karena itu peneliti mengangkat problem belajar siswa kelas VI ini untuk dijadikan bahan kajian atau Penelitian Tindakan Kelas.

Ada pun pembelajaran mengarang melalui penerapan media gambar pada siswa kelas VI SD Negeri 01 Semanget yang kami paparkan disini adalah, pembelajaran mengarang cerita dalam bentuk teks percakapan, dengan menggunakan media gambar sebagai alat bantu mempermudahkan siswa mengungkapkan pikiran atau gagasan ke dalam bentuk karangan. Selama ini pembelajaran mengarang teks percakapan di SD Negeri 01 Semanget hanya dilakukan dengan ceramah, Tanya jawab, dan penugasan. Penerapan media gambar tentunya sesuai fungsinya, salah satunya yaitu, meningkatkan perhatian siswa agar tertarik dengan pembelajaran sehingga tidak membosankan.

Peneliti memilih penerapan media gambar guna meningkatkan keterampilan mengarang siswa kelas VI SD Negeri 01 Semanget, karena pada pembelajaran sebelumnya tanpa media hasil belajar siswa sangat tidak memuaskan. Penggunaan media gambar merupakan salah satu alternatif untuk membantu mengatasi kesulitan siswa dalam memahami materi pelajaran. 
Menurut Siswanto \& Roekhan (2012) Pemilihan penggunaan media didasarkan pada aspek temuan penelitian atau pengalaman. Temuan-temuan peneltian menunjukkan bahwa terdapat hubungan penggunaan jenis media dengan karakteristik belajar siswa yang pada akhirnya juga menentukan hasil belajar siswa.

Lebih lanjut Siswanto \& Roekhan (2012) mengatakan bahwa, siswa akan belajar dengan baik bila ia menggunakan media yang sesuai dengan karakteristik tipe atau gaya belajarnya. Siswa yang memiliki tipe belajar visual akan lebih maksimal dalam pembelajaran bila mereka menggunakan media visual seperti gambar, diagram, video atau film. Siswa memiliki tipe belajar auditif akan lebih maksimal dalam pembelajaran bila mereka menggunakan media audio seperti radio, rekaman suara, atau ceramah guru.

Hasil penelitian Badarudin \& Martha (2012) menyatakan bahwa Pemanfaatan media gambar memiliki dampak positif dalam meningkatkan keterampilan menulis percakapan siswa kelas VI Sekolah Dasar. Sehubungan dengan hal tersebut penelitian ini dilakukan dengan menerapkan media gambar untuk mengatasi permasalahan dalam peningkatan keterampilan mengarang cerita bentuk teks percakapan pada siswa SD Negeri 01 Semanget.

Media adalah alat bantu yang berfungsi; (1) dapat memperjelas penyajian pesan dan informasi sehingga dapat memperlancar dan meningkatkan proses dan hasil belajar, (2) meningkatkan dan mengarahkan perhatian anak sehingga dapat menimbulkan motivasi belajar, dan (3) dapat mengatasi keterbatasan indra, ruang, waktu dan jarak. Penggunaan media membuat pembelajaran menarik dan tidak membosankan. Menurut Santyasa (dalam Siswanto \& Roekhan, 2012) kajian psikologis menyatakan bahwa anak akan lebih mudah mempelajari hal yang konkret dibandingkan dengan abstrak; dari hal yang berada di dekat siswa ke yang jauh; dari yang mudah ke yang sulit; dan dari yang sederhana ke yang rumit. Hasil refleksi diri guru bahwa kegiatan yang telah dilakukan selama ini belum sempurna karena pembelajaran bersifat informatif tidak melibatkan penggunaan media dengan maksimal, maka perlu tindak lanjut melalui pembelajaran yang lebih bermakna. Dasar pendapat ahli di atas, peneliti memandang media gambar sebagai benda konkret yang dapat meningkatkan keterampilan mengarang bagi siswa kelas VI. Dari beberapa masalah belajar yang ditemukan dan telah diuraikan di atas, peneliti mengelompokan, membatasi masalah, dan memfokuskan pada masalah inti yaitu; sulit mengembangkan ide yang kemudian dituangkan ke dalam bentuk tulisan, penggunaan tanda baca, dan penggunaan ejaan dalam menyusun sebuah karya tulisan belum tepat. 


\section{METODE}

Penelitian ini menggunakan rancangan Penelitian Tindakan Kelas (PTK). Penelitian ini menggunakan dua siklus yaitu siklus I dan siklus II. Masing-masing siklus meliputi empat tahap; perencanaan, pelaksanaan tindakan, observasi dan evaluasi, dan refleksi hasil tindakan. Siklus II dilaksanakan setelah siklus I dilakukan dan hasilnya dirasakan belum maksimal serta perlu peningkatan. Secara umum alur pelaksanaaan penelitian kelas menurut kemmis dan Taggard (Dasna, 2012) disajikan pada Gambar 1.

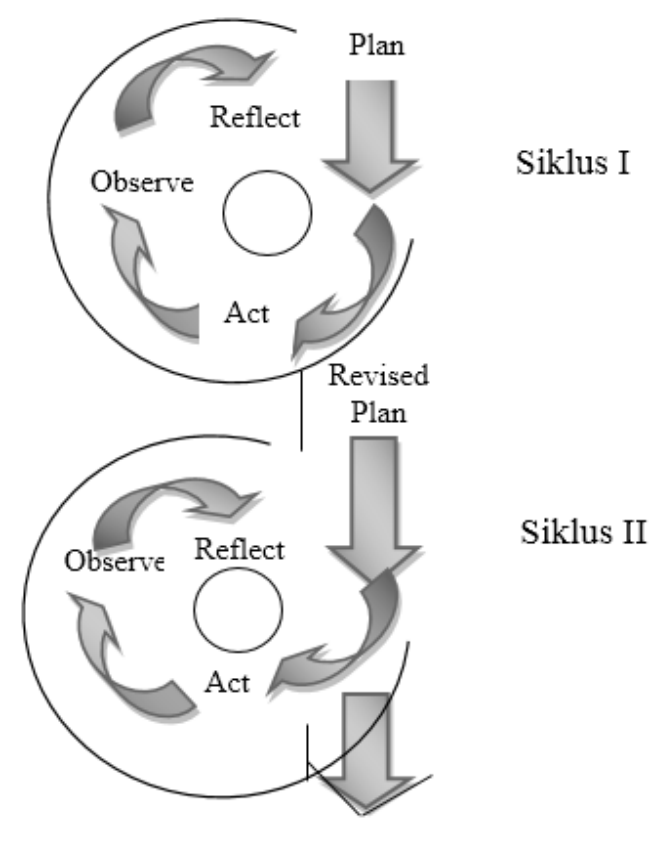

Gambar 1. Model Kemmis \& Taggard (Dasna, 2012)

Subjek penelitian adalah siswa kelas VI SD Negeri 01 Semanget dengan jumlah 38 orang, terdiri dari 18 orang laki-laki dan 20 orang perempuan. Tindakan kelas menggunakan media gambar pada pembelajaran Bahasa Indonesia kompetensi Dasar Menulis. Pembelajaran mengarang dimaksudkan adalah mengarang atau menuliskan cerita bentuk teks percakapan berbagai topik semester I (satu) tahun pelajaran 2017/2018.

Penelitian dilakukan di SD Negeri 01 Semanget Kecamatan Entikong Kabupaten Sanggau. Yaitu pada siswa kelas VI sejumlah 38 siswa, 18 laki-laki, dan 20 perempuan dengan karakter belajar yang berbeda serta latar belakang ekonomi yang berbeda pula. Sarana pembelajaran seperti buku teks Bahasa Indonesia cukup terpenuhi.

Lama penelitian dilakukan selama 6 bulan (Juli s.d Desember 2017). Dalam pelaksanaan penelitian melibatkan wali kelas VI yang bertindak sebagai pengamat saat guru melaksanakan 
kegiatan pembelajaran. Pengumpulan data dihimpun dari data hasil pengamatan dan data hasil belajar siswa. Data yang terkumpul dalam PTK ini dianalisis menggunakan analisis kualitatifkuantitatif. Data hasil pengamatan dianalisis mulai dari siklus satu sampai siklus dua untuk dibandingkan dengan teknik deskriptif persentase. Demikian juga data hasil belajar dianalisis menggunakan deskriptif persentase untuk mencari perbandingan. Dari melihat perbandingan hasil siklus satu dan dua maka akan terlihat ada tidaknya peningkatan.

Prosedur Penelitian Tindakan Kelas ini ada empat tahap; (1) perencanaan tindakan (plan), (2) pelaksanaan tindakan (action), (3) pengamatan (observe), dan (4) evaluasi dan refleksi (reflect). Penelitian ini direncanakan dalam dua siklus. Setiap siklus tiga jam pelajaran (3 x 35 menit). Bahan pelajaran yang digunakan dalam penelitian adalah media konkret (media gambar). Gambar yang telah disediakan dan diberi tema oleh guru. Pemberian tema membantu siswa mempermudah mengembangkan cerita bentuk percakapan. Selain itu buku teks juga digunakan sebagai sumber penting bagi siswa untuk menguatkan pemahaman dalam menulis karangan cerita bentuk teks percakapan. Sebelum media gambar diberikan kepada semua siswa untuk dijadikan media menulis karangan, terlebih dahulu siswa diberi pemahaman dengan memperhatikan gambar yang telah diberi teks cerita bentuk percakapan oleh guru.

\section{HASIL DAN PEMBAHASAN}

\section{Siklus I}

Pelaksanaan kegiatan siklus I ini, peneliti mengikuti skenario pembelajaran yang telah dirancang dalam rencana pelaksanaan pembelajaran (RPP). Pelaksanaan siklus I meliputi empat tahap yaitu perencanaan, tindakan, observasi, dan refleksi. Tahap perencanaan, peneliti membuat perencanaan pembelajaran (RPP), mempersiapkan media gambar, mempersiapkan lembar observasi, dan mempersiapkan tugas dan rubrik penilaian keterampilan mengarang.

Tahap tindakan, pelaksanaan tindakan pembelajaran terdiri dari 3 tahap, yaitu; 1) pendahuluan, 2) kegiatan inti, dan 3) penutup, dengan alokasi waktu 3 x 35 menit. Adapun kegiatan yang dilakukan pada tahap tindakan pembelajaran sebagai berikut: Pada pendahuluan pembelajaran, guru yang sekaligus peneliti menyampaikan kompetensi yang merupakan tujuan pembelajaran yang ingin dicapai. Guru mengaitkan pembelajaran yang akan dilaksanakan dengan realita kehidupan dan menyampaikan skenario pembelajaran yang akan ditempuh. Pada kegiatan inti guru menjelaskan pentingnya sebuah karya tulis dengan disertai tanya jawab. 
Melakukan tanya jawab untuk memberikan kesempatan kepada siswa menggali informasi lebih banyak. Siswa diberikan contoh teks percakapan yang disertai gambar dan sudah diberikan tema untuk diamati. Sebelum diberi tugas, siswa memperhatikan contoh penulisan karangan teks percakapan yang benar oleh guru. Memberikan kesempatan bertanya kepada siswa.

Selanjutnya siswa diberi gambar untuk diamati, kemudian secara berpasangan ditugaskan menulis karangan cerita bentuk teks percakapan berdasarkan gambar yang diberikan. Tujuan siswa ditugaskan secara berpasangan adalah supaya siswa yang kurang dapat belajar dengan temannya atau saling mengeluarkan ide, kemudian ide itu disatukan sehingga pekerjaan menjadi ringan dan diharapakan dapat selesai dengan baik. Selama kegiatan berjalan guru bertindak sebagai fasilitator melakukan bimbingan terhadap siswa terutama pasangan siswa yang masih mengalami kesulitan belajar.

Tahap Pengamatan atau observasi, observasi dilakukan selama pembelajaran berlangsung. Observasi dilakuan bersama teman sejawat. Teman sejawat mencatat peristiwa penting berupa keaktifan siswa secara individu dan hambatan pembelajaran yang terjadi. Hasil observasi direkam dalam lembar observasi. Setelah pembelajaran berakhir, Pekerjaan siswa dikumpulkan untuk dinilai.

Tahap penilaian, penilaian penting dilakukan. Penilaian adalah untuk mengukur ketercapaian ketuntasan belajar. Penilaian dimaksudkan untuk mengetahui apakah siswa telah menguasai materi pelajaran yang telah disajikan guru dengan baik (Sumiati dan Asra, 2009:200). Aspek yang dinilai pada keterampilan mengarang meliputi; kesesuaian isi dengan topik gambar, kemampuan mengembangkan ide/karangan, penggunaan ejaan, dan tanda baca. Kerapian karangan juga tidak luput dari perhatian saat melakukan penilaian. Hasil penilaian dicatat sebagai dokumen penting untuk melihat peningkatan pembelajaran. Catatan hasil belajar siswa dianalisis untuk menentukan tindak lanjut penelitian. Penilaian dilakukan terhadap proses dan hasil akhir pembelajaran.

Tahap refleksi, refleksi dilakukan secara kolaborasi dengan teman sejawat. Refleksi dilakukan setelah melihat catatan hasil belajar. Pada tahap ini tindakan untuk selanjutnya diputuskan. Apabila diputuskan untuk dilanjutkan maka, mulailah berpikir untuk menyusun perencanaan penelitian siklus berikutnya (siklus II). Rekap hasil pengamatan proses siklus I disajikan pada Tabel 1. 
Tabel 1. Indikator keberhasilan proses pada siklis I

\begin{tabular}{|c|c|c|c|}
\hline No. & Aspek & $\begin{array}{l}\text { Pencapaian } \\
\text { siklus I }\end{array}$ & Cara mengukur \\
\hline 1 & $\begin{array}{l}\text { Keaktifan siswa } \\
\text { mengajukan pertanyaan }\end{array}$ & $34 \%$ & $\begin{array}{l}\text { Dihitung dari jumlah siswa bertanya per } \\
\text { jumlah keseluruhan siswa }\end{array}$ \\
\hline 2 & $\begin{array}{l}\text { Keatifan siswa dalam } \\
\text { mengikuti pelajaran }\end{array}$ & $89 \%$ & 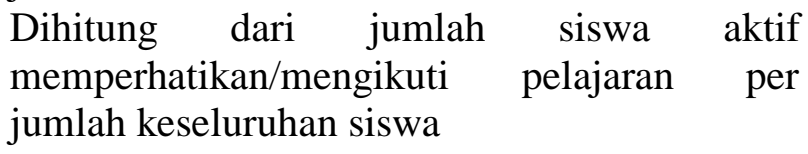 \\
\hline 3 & $\begin{array}{l}\text { Ketepatan waktu siswa } \\
\text { menyelesaikan tugas }\end{array}$ & $84 \%$ & $\begin{array}{l}\text { Dihitung dari jumlah siswa menyelesaikan } \\
\text { tugas tepat waktu dibagi jumlah keseluruhan } \\
\text { siswa }\end{array}$ \\
\hline
\end{tabular}

Pada siklus I ini siswa yang aktif bertanya ada 13 siswa atau 34\%. Siswa yang bertanya adalah belum paham, akan tetapi mereka ini memiliki rasa ingin tahu yang tinggi. Keaktifan siswa mengikuti pembelajaran 34 siswa atau 89\%. Sedangkan siswa yang menyelesaikan pekerjaan tepat waktu adalah 32 siswa atau $84 \%$.

Ketuntasan belajar Bahasa Indonesia kelas VI dengan $\mathrm{KKM}=65$, terdapat 55\% (21 siswa/i) dari 38 siswa tuntas dan masih ada 45\% (17 siswa/i) yang belum tuntas. Hasil musyawarah kolaborator terhadap analisa penilaian hasil belajar, telah menemukan penyebab ketidaktuntasan 17 siswa tersebut terdapat pada masih rendahnya kemampuan dalam mengembangkan ide/karangan, serta penggunaan tanda baca yang belum tepat. Sedangkan 21 siswa yang sudah tuntas masih dipandang perlu untuk ditingkatkan kembali.

\section{Siklus II}

Siklus II dilakukan karena pelaksanaan siklus I belum optimal. Pelaksanaan siklus II berbeda dengan siklus I. Perbedaan terletak pada cara kerja siswa dan penggunaan media. Pada pelaksanaan kegiatan siklus II, langkah pembelajaran dibedakan pada penekanan tanggung jawab kerja siswa yang bersifat individu. Siswa mengerjakan tugas secara mandiri. Sedangkan pada siklus I tanggung jawab kerja berpasangan. Pada pembelajaran siklus II, siswa tidak diberikan media gambar langsung dalam bentuk selebaran, akan tetapi siswa disuruh mengamati gambar yang ditayangkan melalui media infokus. Pada siklus II siswa mengerjakan tugas secara individual. Maksud dan tujuan agar siswa mampu dan mandiri dalam mengerjakan tugas. Selain itu supaya siswa yang pandai tidak selalu memonopoli mengerjakan pekerjaan, sementara siswa

yang kurang tidak sebagai penenrima terus. Tentunya kemandirian itu sudah memiliki dasar yang diperoleh melalui kerja berpasangan pada siklus I. Dengan demikian guru dapat mengetahui 
kemampuan individu siswa secara maksimal melalui hasil pekerjaannya. Pada akhirnya kemampuan individu yang diharapkan.

Media gambar yang disertai contoh karangan teks percakapan ditayangkan di depan kelas. Siswa mengamati media tersebut. Gambar yang dijadikan tugas siswa ditayangkan kemudian. Selanjutnya siswa ditugaskan menulis karangan percakapan berdasarkan gambar yang ditayangkan. Penggunaan media infokus juga menambah ketertarikan siswa mengamati gambar. Tayangan gambar melalui infokus adalah bentuk kreativitas guru dalam memperdayakan media sesuai fungsinya. Penggunaan infokus juga menarik perhatian siswa agar mau memperhatikan materi pelajaran yang disajikan guru di depan kelas. Mengarang cerita bentuk percakapan menggunakan media gambar adalah membantu siswa untuk menemukan ide serta mengembangkan karangannya dengan terfokus. Pada akhirnya yang diharapkan sesungguhnya adalah siswa mampu menulis karangan berdasarkan idenya. Adapun penggunaan media gambar dan sebagainya adalah dalam tahap pembelajaran. Selama pembelajaran berlangsung, pengamatan proses tetap dilakukan oleh peneliti dan teman sejawat. Catatan rekap hasil pengamatan disajikan pada Tabel 2.

Tabel 2. Indikator keberhasilan proses pada siklus II

\begin{tabular}{llcl}
\hline No. & \multicolumn{1}{c}{ Aspek } & $\begin{array}{c}\text { Pencapaian } \\
\text { siklus I }\end{array}$ & \multicolumn{2}{c}{ Cara mengukur } \\
\hline 1 & $\begin{array}{l}\text { Keaktifan siswa } \\
\text { mengajukan } \\
\text { pertanyaan } \\
\text { keatifan siswa dalam } \\
\text { mengikuti pelajaran }\end{array}$ & $7,89 \%$ & $\begin{array}{l}\text { Dihitung dari jumlah siswa bertanya per } \\
\text { jumlah keseluruhan siswa }\end{array}$ \\
3 & $100 \%$ & $\begin{array}{l}\text { Dihitung dari jumlah siswa aktif } \\
\text { memperhatikan/mengikuti pelajaran per } \\
\text { jumlah keseluruhan siswa }\end{array}$ \\
$\begin{array}{l}\text { Ketepatan waktu } \\
\text { siswa menyelesaikan } \\
\text { tugas }\end{array}$ & $92 \%$ & $\begin{array}{l}\text { Dihitung dari jumlah siswa } \\
\text { menyelesaikan tugas tepat waktu dibagi } \\
\text { jumlah keseluruhan siswa }\end{array}$ \\
\hline
\end{tabular}

Pada siklus II, keaktif siswa bertanya ada 3 siswa atau 7.89\%. artinya hampir semua siswa sudah memahami materi pelajaran. Keaktifan siswa mengikuti pembelajaran 38 siswa atau 100\%. Sedangkan siswa yang menyelesaikan pekerjaan tepat waktu adalah 35 siswa atau 92\%. Semuanya tuntas, bahkan beberapa siswa mendapat nilai sangat baik. Peningkatan hasil belajar mengarang melalui penerapan media gambar keseluruhan lebih jelas dapat dilihat pada grafik rekap nilai Siklus I dan II, disajikan pada Gambar 1. 


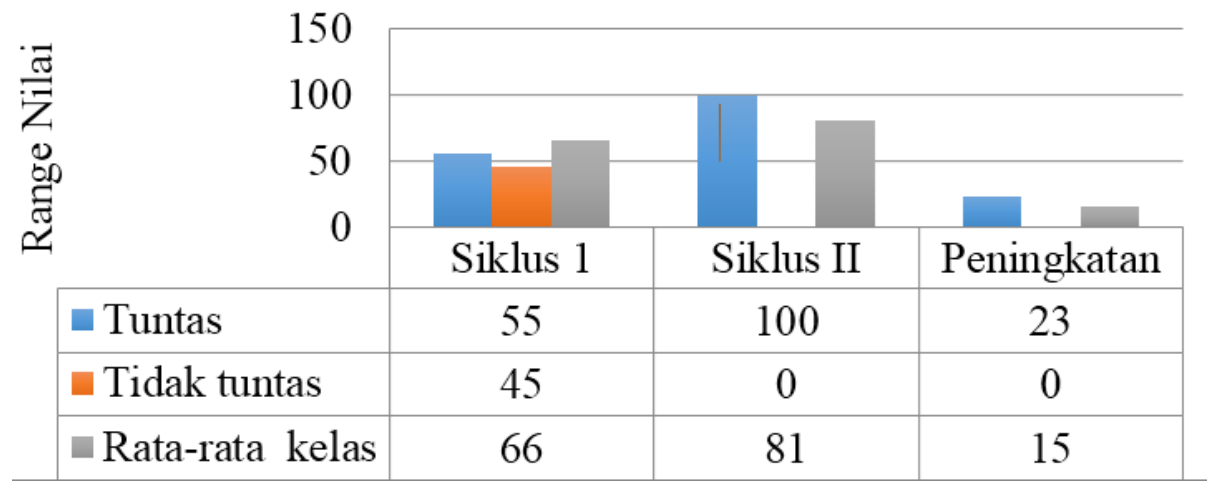

Gambar 1. Rekapitulasi hasil akhir siklus I dan II

Mencermati pada Gambar 1 dapat dilihat bahwa rekap hasil akhir pembelajaran siklus I dan Siklus II di atas terdapat peningkatan rata-rata kelas dari 66 menjadi 81 dengan peningkatan 15 dan peningkatan ketuntasan $23 \%$.

Dari segi proses, hasil pengamatan menunjukkan keaktifan siswa bertanya cukup besar yaitu 13 siswa. Hal ini menandakan kekurangpahaman siswa tersebut, di sisi lain siswa yang bertanya memiliki rasa ingin tahu yang besar. Pada siklus ini masih ada siswa yang kurang aktif mengikuti pembelajaran. Ketepatan waktu menyelesaikan pekerjaan masih perlu ditingkatkan. Dari segi hasil, nilai tertinggi 81 dan nilai terendah 44. Dengan rata-rata kelas 66. Sedangkan ketuntasan belajar terdapat 21 siswa/i (55\%) tuntas dan masih ada 17 siswa/i (47\%) belum tuntas.

Penyebab ketidaktuntasan 17 siswa pada siklus I ini dikarenakan siswa belum optimal mengikuti pembelajaran. Namun bila dibandingkan dengan pembelajaran sebelumnya tanpa menggunakan media gambar siswa tidak tuntas 58\% (22 siswa/i), pembelajaran sikus I ini sudah menunjukkan banyak perubahan. Artinya penerapan media gambar memang memiliki dampak terhadap proses pembelajaran. Besarnya jumlah siswa yang belum tuntas maka, peneliti melanjutkan tindakan penelitian ke siklus II (Encemi dan Badarudin: 2012).

Pada siklus II siswa yang bertanya 7,89\% (3 siswa), ini menandakan tinggal 3 siswa yang masih kurang memahami meteri pelajaran. Keaktifan siswa mengikuti pembelajaran sangat baik $(100 \%)$ dan siswa menyelesaikan tugas tepat waktu 92\%. Yaitu tugas selesai sebelum kegiatan pembelajaran berakhir. Hasil belajar siklus II, perolehan nilai siswa tertinggi mencapai 100, nilai terendah 69, dan rata-rata kelas 81 . Ketuntasan hasil belajar siswa 100\%. Artinya tidak ada siswa yang mendapat nilai mengarang cerita di bawah KKM Bahasa Indonesia kelas VI yaitu 65. 
Kesungguhan siswa dalam mengikuti pembelajaran berdampak pada meningkatnya hasil belajar, sehingga siklus II kegiatan penelitian pembelajaran di kelas berhasil.

Siklus kesatu merupakan siklus awal yang ditandai dengan proses pembelajaran yang belum optimal. Hal tersebut terindikasi dengan ketuntasan baru mencapai 55\% (17 siswa) belum tuntas. Untuk itu diupayakan peningkatan pembelajaran pada siklus kedua. Siklus kedua menunjukkan adanya peningkatan yaitu rata-rata kelas mencapai 81 dengan ketuntasan mencapai $100 \%$ (tuntas semua). Peningkatan prestasi belajar sebesar 15 atau 23\%. Indikator keberhasilan terpenuhi.

Media adalah alat bantu bagi siswa dalam memahami dan memperoleh informasi yang dapat didengar dan dilihat oleh panca indera sehingga pembelajaran dapat berhasil guna dan berdaya guna (Eka Prihatin, 2008). Fungsi media menurut Santyasa (dalam Siswanto \& Roekhan, 2012) diantaranya sebagai berikut; (1) dapat memperjelas penyajian pesan dan informasi sehingga dapat memperlancar dan meningkatkan proses dan hasil belajar, (2) meningkatkan dan mengarahkan perhatian anak sehingga dapat menimbulkan motivasi belajar. Berdasarkan pendapat yang merupakan hasil kajian para ahli di atas, bila dikaitkan dengan hasil belajar siklus kedua siswa aktif prestasi belajar meningkat maka, penggunaan media dalam hal ini media gambar dalam pembelajaran selaras dengan apa yang diharapkan dalam penelitian ini. Oleh karena itu, penggunaan media pada setiap kegiatan pembelajaran perlu menjadi perhatian khusus bagi para guru. Hasil rata-rata siklus kedua adalah 81 dan telah melampaui KKM 65. Penerapan media gambar pada kegiatan pembelajaran berdampak pada meningkatnya keterampilan mengarang Bahasa Indonesia siswa kelas VI SD Negeri 01 Semanget.

\section{SIMPULAN}

Dari uraian hasil penelitian di atas dapat ditarik kesimpulan sebagai berikut, penerapan media gambar pada kegiatan pembelajaran sangat membantu siswa dalam memahami materi pelajaran. Penerapan media gambar pada pembelajaran bahasa Indonesia mengarang dapat meningkatkan keterampilan mengarang pada siswa kelas VI SD.

\section{DAFTAR PUSTAKA}

Dasna, I. W. (2012). Penelitian tindakan kelas. Malang: PT. Pertamina (Persero)-Universitas Negeri Malang. 
Encemi, Martha \& Badarudin. (2012). Pemanfaatan media gambar untuk meningkatkan keterampilan menyusun percakapan siswa kelas VI Sekolah Dasar SDN 16 Kenaman Kabupaten Sanggau. prosiding seminar nasional. teqip 2012.

Koswara, Deni \& Halimah. (2008). Bagaimana menjadi guru kreatif?. Bandung: PT. Pribumi Mekar.

Pusat Pembinaan dan Pengembangan Bahasa. (2008). Kamus bahasa indonesia elektronik, Jakarta: Pusat Bahasa.

Prihatin, E. (2008). Guru sebagai fasilitator. Bandung: PT. Karsa Mandiri Persada.

Santoso, Anang \& Heri S. (2012). Pendalaman materi bahasa indonesia. Malang: PT Pertamina dan Universitas Negeri Malang.

Siswanto, Wahyudi \& Roekhan. (2012). Petunjuk pembuatan dan penggunaan media pembelajaran alternatif. Malang: PT Pertamina dan Universitas Negeri Malang.

Sumiati \& Asra. (2009). Metode pembelajaran. Bandung: CV. Wacana Prima

Tagur \& Herman, Y. (2012). Penggunaan media gambar seri untuk meningkatkan kemampuan menulis karangan sederhana siswa kelas iii sdk rangga kecamatan lembor Kabupaten Manggarai Barat. J-TEQIP. (Jurnal Peningkatan Kualitas Guru), III (1), 42-46. 